\title{
PSYCHOLOGICAL CHARACTERISTICS OF ENTREPRENEURSHIP POTENTIAL AMONG VOCATIONAL HIGH SCHOOL STUDENTS
}

\author{
Syarifah Farradinna ${ }^{1, *}$, Icha Herawati ${ }^{2}$, Ajeng Hari Mulyani ${ }^{3}$ \\ 1,2,3 Department of Psychology, Universitas Islam Riau, Jl. Kaharuddin Nasution 113 Pekanbaru, Riau 28284, Indonesia \\ E-mail: syarifah.farradinna@psy.uir.ac.id * \\ *Corresponding Author
}

\begin{abstract}
This study investigates the psychological concept that affects the intention of vocational high school students to become entrepreneurs. This study aims to predict the most effective psychological step to demonstrate the psychological characteristics of entrepreneurs of vocational high school students. Participants in this study were vocational high school students in the Department of Mechanical and Building Engineering. 206 students were selected as the sample of the study with a random sampling technique. This study employed a set of questionnaires contains a measurement scale consisting of entrepreneurial capacity, entrepreneurial belief, entrepreneurial consciousness, entrepreneurial motivation, and entrepreneurial determination. Statistical analysis was performed with Confirmatory Factorial Analysis (CFA) to determine whether the fit model is unidimensional and to determine the significance value measurement model independently, assisted with statistical software Mplus. The results revealed that entrepreneurial belief and motivation are the highest factors. The results also reported that there is a significant difference in entrepreneurial belief in different gender. The entrepreneurial belief characteristics of male students were higher than female students. This implies that there is a need to emphasize psychological entrepreneurship education that leads to increased self-confidence in female students. In addition, it is necessary to do psycho-education to prepare students as entrepreneurs.
\end{abstract}

Keywords: entrepreneurship potential, psychological characteristics, vocational school student

\section{INTRODUCTION}

Entrepreneurship has long been viewed as a method of encouraging creativity and technical development, stimulating competitiveness, and generating opportunities that contribute to economic growth and national stability [1]. The Government of the Republic of Indonesia through the Ministry of National Education emphasizes the importance of Vocational Schools not only to create human resources who are ready to work, but also to prepare independent human resources who create employment opportunities to reduce individual dependence on employment. On the other hand, while compared with Malaysia and Singapore, Indonesia has not proved entrepreneurs as the priority choice of professional career among students. Only 1.65 percent of the total population of Indonesia choose a career as an entrepreneur [2].

Entrepreneurial activity among young people should be early implanted so that the students can choose a career in the future as entrepreneurs [3]. The growth of entrepreneurial talent among youths is crucial to retaining a competitive edge. Several entrepreneurial psychological experts suggest that regardless of age, people can start a business [4]. However, the current trend of entrepreneurs shows that they started their businesses since young [5]. Furthermore, Zhang \& Zhang [17] reported that the higher the level of education, the less effect entrepreneurship education has on the entrepreneurship path. Educators and stakeholders should be aware of the value of quality entrepreneurship education in enhancing entrepreneurial talent among students [6].

To respond to this issue, entrepreneurship has been regulated as a compulsory subject in the curriculum for all secondary schools in Indonesia. Although this idea faces many doubts in the process, entrepreneurship education is prioritized to be taught in high schools [7]. Students are challenged to explore new ideas and this system encourages students to choose their 
careers as entrepreneurs [8]. Entrepreneurship education in the curriculum for Vocational High Schools in Indonesia was stated in Presidential Instruction of the Republic of Indonesia number 4, 1995 concerning the national movement to socialize and cultivate entrepreneurship. It is expected to produce better-quality human resources, equipped with not only skills and abilities, but also have personality qualities and psychological mentality of entrepreneurs. Public and private vocational education jointly organized this entrepreneurship-based curriculum so that students were able to be encouraged to pull out of dependence on the increasingly limited job. However, this action is not sufficient to encourage students and education providers to make entrepreneurs a career priority.

In addition to acquiring entrepreneurial knowledge and skill through entrepreneurship education, entrepreneurial learning is seen to also include psychological factors [9]-[13]. Previous organizational behavior researchers have found that psychological factors are the most motivating factor for individuals to choose a career as an entrepreneur [14]. Psychological characteristics according to Zhang \& Zhang [15] play an important role in developing entrepreneurial interest among students. They are an important factor in entrepreneurship education [16]. Psychological characteristics can influence someone to take on the role of an entrepreneur. Entrepreneurial capacity factors including organization and management, interpersonal relationships, innovation, and the physical quality and soul of individuals are the capital for individuals to build entrepreneurial potential.

To understand the concept of psychological factors that affect the intention to become entrepreneurs, it should be viewed from different perspectives. Intrinsic characteristics such as self-efficacy beliefs of individuals or allegedly associated with thinking, emotions, and behavior of individuals push themselves to become entrepreneurs to reach their goals and success [14]. The researchers predict that psychological characteristics are the main gauge of individual basis to transform into entrepreneurs. Entrepreneurial researchers have studied these problems from different points of view. The characteristics of entrepreneurial consciousness more likely to involve emotions, the need for achievement, motivation, and the application of values in choosing entrepreneurship as their career [17].

Psychological characteristics are important not only for entrepreneurship but also for professional development in the future. It is important to determine the entrepreneurial psychological characteristics that most influence vocational high school students to provide effective entrepreneurship education for the students. This study focuses on the most effective measures which could be the most appropriate to show the psychological characteristics of entrepreneurship of vocational high school students.

\section{METHOD}

This study involved 206 people from 960 vocational high school students in the Department of Mechanical and Building Engineering, Pekanbaru city, Indonesia selected with a random sampling technique. Psychological characteristics of entrepreneurship are described in five factors that decisive individual characteristics namely capacity, beliefs, consciousness, motivation, and entrepreneurial determination [15]. A set of questionnaires that contains a measurement scale consisting of capacity, belief, awareness, motivation, and entrepreneurial determination was used. In the implementation, the headmaster and academic staff assisted the researcher in distributing questionnaires. The questionnaire consisted of 31 items on a scale measuring the psychological characteristics of entrepreneurship. The Likert scale was used in the 5-point criteria (Strongly Agree scored as 5 to Strongly Disagree scored as 1) and was modified to adjust the language and culture in Indonesia. 
Statistical analysis was performed with Confirmatory Factorial Analysis (CFA) to determine whether the fit model is unidimensional and to determine the significance value measurement model independently. The analysis was conducted with the M-plus [18], in which the program can perform linear and nonlinear data analysis to facilitate the model fit.

\section{RESULTS AND DISCUSSION}

The unidimensional test using MPlus was conducted to test the construct validity of each item of psychological characteristics of entrepreneurship [19]. The steps were conducted concerning the significant value of Chi-Square $p$ $<0.05$. It is performed to determine the measurement model independently of the measurement error correlation that can cause multifactorial. This measurement error relief can form a correlation that aims to obtain a fit model. When a model fit is obtained, the item can be analyzed further to test the positive coefficient. When the factor loadings are higher than 1.9, then this item is significant in the measurement factors to be measured. Meanwhile, in terms of loading factor $(>0.5)$, it was used to show the correlation value between indicators and latent constructs once known as the model fit.

The five factors that were divided into 31 items indicated a unifactorial trait, thus the next step was performed by analyzing the CFA and modifying the model for measurement error relief. Chi-Square $=491.672(\mathrm{df}=418, p=$ $0.0075, R M S E A=0.029$ ). Table 1 shows that the $\mathrm{t}$-value for the loading factors coefficient for all 31 items, there is 1 item (Item 17) that is not valid with $\mathrm{z}$ value $<1.96$. The CFA path diagram model can be seen in Figure 1.

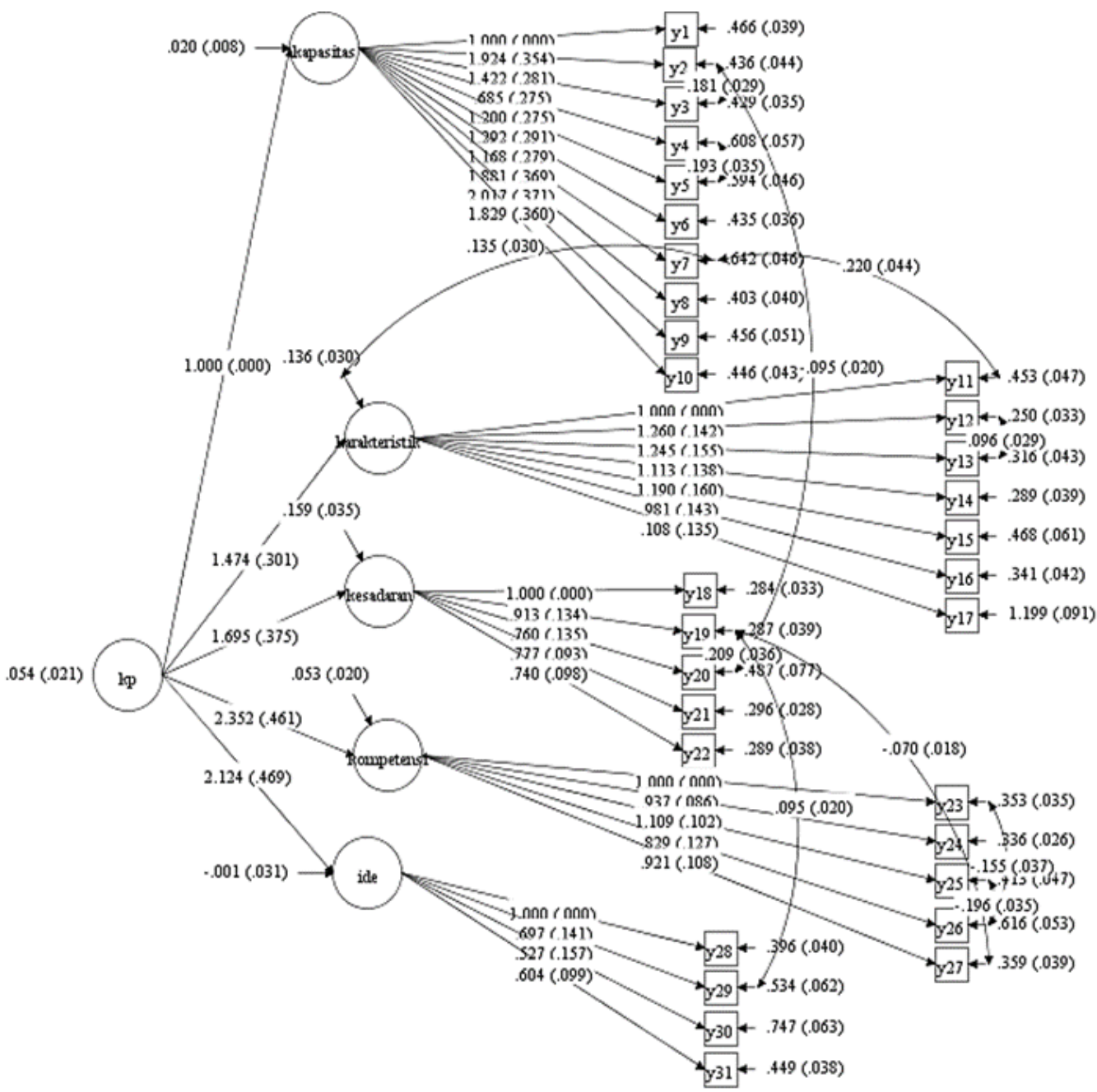

Figure 1. Model Diagram of Psychological Characteristics of Entrepreneurship 
Table 1. Value of Loading Factor Psychological Characteristics of Entrepreneurship

\begin{tabular}{|c|c|c|c|c|c|}
\hline No & Statement & Estimate & Std Error & t-value & \\
\hline \multicolumn{6}{|c|}{ The Dimension of Entrepreneurial Capacity } \\
\hline 1 & I always make a plan before doing a job & 1.000 & 0.000 & 999.000 & Ref. Item \\
\hline 2 & $\begin{array}{l}\text { I am active in various activities related to } \\
\text { entrepreneurship }\end{array}$ & 1.924 & 0.354 & 5.439 & Valid \\
\hline 3 & $\begin{array}{l}\text { I am good at learning related to } \\
\text { entrepreneurship }\end{array}$ & 1.422 & 0.281 & 5.063 & Valid \\
\hline 4 & I can cooperate with others & 0.685 & 0.275 & 2.490 & Valid \\
\hline 5 & Everything that I planned, I had to do & 1.200 & 0.275 & 4.364 & Valid \\
\hline 6 & $\begin{array}{l}\text { I accept other people's opinions and suggestions } \\
\text { related to entrepreneurship }\end{array}$ & 1.292 & 0.291 & 4.444 & Valid \\
\hline 7 & I am personally resilient & 1.168 & 0.279 & 4.191 & Valid \\
\hline 8 & $\begin{array}{l}\text { I like to participate in entrepreneurial-related } \\
\text { activities }\end{array}$ & 1.881 & 0.369 & 5.093 & Valid \\
\hline 9 & $\begin{array}{l}\text { I have a high curiosity related to } \\
\text { entrepreneurship }\end{array}$ & 2.017 & 0.371 & 5.439 & Valid \\
\hline 10 & I train my management skills & 1.829 & 0.360 & 5.086 & Valid \\
\hline \multicolumn{6}{|c|}{ The Dimensions of Entrepreneurial belief } \\
\hline 11 & I believe having a strong mental & 1.000 & 0.000 & 999.000 & Ref. Item \\
\hline 12 & I do not give up easily to difficulties & 1.260 & 0.142 & 8.881 & Valid \\
\hline 13 & I am not easily discouraged & 1.245 & 0.155 & 8.017 & Valid \\
\hline 14 & If I fail, I still face it bravely & 1.113 & 0.138 & 8.052 & Valid \\
\hline 15 & I like challenges & 1.190 & 0.160 & 7.415 & Valid \\
\hline 16 & I am optimistic about life & 0.981 & 0.143 & 6.860 & Valid \\
\hline 17 & I don't like to be ordered by others & 0.108 & 0.135 & 0.801 & Not Valid \\
\hline \multicolumn{6}{|c|}{ The Dimension of Entrepreneurial consciousness } \\
\hline 18 & I think being an entrepreneur requires courage & 1.000 & 0.000 & 999.000 & Ref. Item \\
\hline 19 & I think, to be entrepreneurs willing to take risks & 0.913 & 0.134 & 6.803 & Valid \\
\hline 20 & $\begin{array}{l}\text { I think, being an entrepreneur must have a spirit } \\
\text { of competition }\end{array}$ & 0.760 & 0.135 & 5.622 & Valid \\
\hline 21 & $\begin{array}{l}\text { I think innovation is essential to business } \\
\text { success }\end{array}$ & 0.777 & 0.093 & 8.369 & Valid \\
\hline 22 & I'm trying to build the credibility & 0.740 & 0.098 & 7.583 & Valid \\
\hline \multicolumn{6}{|c|}{ The Dimensions of Entrepreneurial Motivation } \\
\hline 23 & $\begin{array}{l}\text { I am enthusiastic about matters related to } \\
\text { entrepreneurship }\end{array}$ & 1.000 & 0.000 & 999.000 & Ref. Item \\
\hline 24 & As an entrepreneur, I can show my abilities & 0.937 & 0.086 & 10.910 & Valid \\
\hline 25 & Being an entrepreneur is my dream & 1.109 & 0.102 & 10.828 & Valid \\
\hline 26 & I have never been bored with my life & 0.829 & 0.127 & 6.546 & Valid \\
\hline 27 & Being an entrepreneur makes me valuable & 0.921 & 0.108 & 8.549 & Valid \\
\hline \multicolumn{6}{|c|}{ The Determining Dimensions of Entrepreneurship } \\
\hline 28 & $\begin{array}{l}\text { I am actively studying to achieve success to } \\
\text { become an entrepreneur }\end{array}$ & 1.000 & 0.000 & 999.000 & Ref. Item \\
\hline 29 & $\begin{array}{l}\text { I think, being an entrepreneur must have various } \\
\text { solutions }\end{array}$ & 0.697 & 0.141 & 4.935 & Valid \\
\hline 30 & The thing I decided, always attested & 0.527 & 0.157 & 3.363 & Valid \\
\hline 31 & $\begin{array}{l}\text { In various opportunities, I always consider the } \\
\text { advantages and disadvantages. }\end{array}$ & 0.604 & 0.099 & 6.104 & Valid \\
\hline
\end{tabular}

This study also describes the analysis of the difference by measuring the t-test using an empirical score of 206 vocational school students consisting of male students $(\mathrm{N}=130)$ and female students $(\mathrm{N}=76)$. Based on the analysis performed descriptively, it was identified the differences are not significant. This result can be seen in Table 2 . 
The provisions of the entrepreneurial factor in male students occupy a score greater than five factors of psychological characteristics of entrepreneurship that exist for $\mathrm{M}=50.15$, SD $=7.10$. In addition, female students showed an entrepreneurial belief factor of $\mathrm{M}=51.26, \mathrm{SD}=$ 9.93. Differences based on the psychological characteristics of entrepreneurship in terms of gender are not significant. The significant differences in psychological characteristics of entrepreneurship in terms of gender in vocational high school students are presented in Table 3.

Two characteristic factors are showing significant t-test values, namely the factor of entrepreneurial belief and motivation. A similar conclusion was reached by Zhang \& Zhang [15] who claimed that an individual's belief in the ability itself is an aspect that influenced the development of adolescent personality as an entrepreneur. Furthermore, learning from the past and prioritize economic, social, and cultural rights are cornerstones of decision-making as an entrepreneur [20], [21]. A resilient personality is a key to the success of an individual being able to withdraw himself from a difficult situation [22].

The entrepreneurial belief in male vocational students shows higher than female students. In line with the characteristic factors of entrepreneurial motivation, it also shows that male students are significantly higher than female students.

Based on the analysis of the psychological characteristics of entrepreneurship, it has been found that the entrepreneurial belief factor is the one that most shows the difference in characteristics between male and female students. Psychological factors of entrepreneurship show that male vocational high school students show higher entrepreneurial confidence than female students. While other entrepreneurial psychological characteristics factors almost found the same score. Entrepreneurial beliefs play an important role in both male and female students in entrepreneurship.

Individuals with high entrepreneurial beliefs are predicted to show better work skills excited by ideas and innovation for their business development and can choose between having effort and perseverance to achieve goals [15]. Sadriwala \& Khan [23] also reported that individuals with self-confidence can receive and manage the challenges and take risks with patients in resolving issues related to business. An entrepreneur shows courage in taking risks, respond with its opportunities, and take advantage of the best possible [24]. It is a cognitive process in the form of an activity carried out deliberately, which is in the perspective of psychology considered as planned behavior [25]. This is also consistent with what has been found that certain personality characteristics influence entrepreneurial decisions, and it was discovered that success motivation and risk-taking courage were contrasted in two groups: managers and employees. Another research contrasted the personalities of entrepreneurs and ordinary people, finding that employers had higher levels of accountability and the consistency of hard workers [26]. Meanwhile, achievement motivation, risk-taking tendencies, creativity, self-control, self-efficacy, and openness to experience are common psychological characteristics of entrepreneurs [5][27].

Table 2. Descriptive Results of the Psychological characteristics of Entrepreneurship between Male and Female Students

\begin{tabular}{lcccc}
\hline \multirow{2}{*}{ Dimension } & \multicolumn{2}{c}{ Male } & \multicolumn{2}{c}{ Female } \\
& Mean & SD & Mean & SD \\
\hline Entrepreneurial Capacity & 50.08 & 8.75 & 49.86 & 9.60 \\
Entrepreneurial Belief & 49.27 & 9.04 & 51.26 & 9.93 \\
Entrepreneurial Consciousness & 50.07 & 8.72 & 49.87 & 10.51 \\
Entrepreneurial Motivation & 49.74 & 8.79 & 50.44 & 9.24 \\
Entrepreneurial Determine & 50.15 & 7.10 & 49.74 & 7.38 \\
\hline
\end{tabular}


Table 3. The Significant Differences in Psychological Characteristics of Entrepreneurship

\begin{tabular}{ccccc}
\hline Dimensions & Gender & $\mathrm{N}$ & Mean and SD & $\mathrm{T}$ \\
\hline \multirow{2}{*}{ Entrepreneurial Capacity } & Male & 130 & $49.86 \pm 9.6$ & $\mathrm{t}=-0.173$ \\
& Female & 76 & $50.08 \pm 8.75$ & $\mathrm{t}=-0.169$ \\
Entrepreneurial belief & Male & 130 & $51.26 \pm 9.93$ & $\mathrm{t}=1.469$ \\
& Female & 76 & $49.27 \pm 9.04$ & $\mathrm{t}=1.434$ \\
Entrepreneurial consciousness & Male & 130 & $49.87 \pm 10.51$ & $\mathrm{t}=-0.148$ \\
& Female & 76 & $50.07 \pm 8.72$ & $\mathrm{t}=-0.141$ \\
Entrepreneurial Motivation & Male & 130 & $50.44 \pm 9.24$ & $\mathrm{t}=0.541$ \\
& Female & 76 & $49.74 \pm 8.79$ & $\mathrm{t}=0.534$ \\
Entrepreneurial Motivation & Male & 130 & $49.74 \pm 7.38$ & $\mathrm{t}=-0.399$ \\
& Female & 76 & $50.15 \pm 7.1$ & $\mathrm{t}=-0.395$ \\
\hline
\end{tabular}

Meanwhile, this study also indicated that the entrepreneurial motivation factor of male students tended to be higher than female students. This was in line with research by Sullivan \& Meek [28] who found that men were able to show better results of examining entrepreneurial motivation than women. Israr \& Saleem [29] also concluded that female entrepreneurial intentions have a slightly negative trend as compared to male students' entrepreneurial intentions, indicating that female students are less interested in entrepreneurship. Even so, women did not rule out the possibility of taking the same role, but according to the researchers, most women in business often experience loss compared to men.

\section{CONCLUSION}

This study investigates the psychological concept that affects the intention of vocational high school students to be entrepreneurs. This study demonstrates the psychological characteristics of entrepreneurs of vocational high school students. The results showed that two characteristic factors with significant values, namely entrepreneurial belief and motivation. The results also reported that the entrepreneurial belief characteristics of male students were higher than female students. The results of this study imply that there is a need to emphasize psychological entrepreneurship education that leads to increased self-confidence in female students. In addition, it is necessary to do psycho-education to prepare students as entrepreneurs. This study confirms the findings which have been found. Further studies need to be developed from this study to emphasize entrepreneurship education that leads to selfconfidence and self-motivation for female students. It is known that women entrepreneurs have started to play a role in the business sector today.

\section{REFERENCES}

[1] C. Holmgren and J. From, "Taylorism of the mind: entrepreneurship education from a perspective of educational research.," Eur. Educ. Res. J., vol. 4, no. 4, pp. 382-390, 2005.

[2] L. Thaib and $\mathrm{B}$. Che $\mathrm{Pa}$, "Islamic business leaderhip modelling for sustainable development," Int. $J$. Multidiscip. Acad. Res., vol. 2, no. 1, pp. 25-32, 2014.

[3] S. Walter and J. Block, "Outcomes of entrepreneurship education: An institutional perspective," J. Bus. Ventur., vol. 31, no. 2, pp. 216-233, 2015.

[4] N. Shaheen and S. Al-Haddad, "Entreprenurial self-efficacy and entrepreneurial behavior," Int. J. Dev. Sustain., vol. 7, no. 10, pp. 2385-2402, 2018.

[5] D. K. Hsu, J. Wiklund, and S. Anderson, "Entrepreneurial exit intentions and the business-family interface," $J$. Bus. Ventur., vol. 31, no. 6, pp. 613-627, 2016.

[6] B. M. Musa and D. M. Semasinghe, "Enterprise education and venture initiative in developing entrepreneurial potentials," 2014. 
[7] U. Hytti and J. Heinonen, "Heroic and humane entrepreneurs: identity work in entrepreneurship education," Educ. + Train., vol. 55, no. 8/9, pp. 886-898, 2013.

[8] N. . Elert, F. Andersson, and Wennberg, "The impact of entrepreneurship education in high school on long-term entrepreneurial performance," J. Econ. Behav. Organ., vol. 11, no. 1, pp. 1-30, 2014.

[9] V. Samydevan, S. Piaralal, A. K. Othman, and Z. Osman, "Impact of psychological traits, entrepreneurial education and culture in determining entrepreneurial intention among preuniversity students in Malaysia," Am. $J$. Econ., vol. 5, no. 2, pp. 163-167, 2015.

[10] Z. Hong, T. Hong, Z. Cui, and W. Luzhuang, "Entrepreneurship quality of college students related to entrepreneurial education empirical study on psychological and behavioral characteristics," Energy Procedia, vol. 17, pp. 1907 - 1913, 2012.

[11] N. Ozaralli and N. K. Rivenburgh, "Entrepreneurial intention: antecedents to entrepreneurial behavior in the U.S.A. and Turkey," J. Glob. Entrep. Res., vol. 6, no. 3, 2016.

[12] R. Mokhtar, M. A. Zulkifli, and Y. Zainuddin, "Psychological characteristic and entrepreneurial intention: the mediation effect of TPB," 2016.

[13] A. Dinis, A. M. F. do Paço, J. J. M. Ferreira, and M. Raposo, "Psychological characteristics and entrepreneurial intentions among secondary students," Educ. Train., vol. 55, no. 8/9, pp. 763780, 2013.

[14] N. Chatterjee and N. Das, "Key psychological factors as predictors of entrepreneurial success: A conceptual framework," Acad. Entrep. J., vol. 21, no. 1, pp. 102-114, 2015.

[15] H. Zhang and Y. Zhang, "Psychological characteristic of entrepreneurship of college students in China," Sci. Res., vol. 4, no. 3, pp. 159-164, 2013.

[16] S. Ollila and K. W. Middleton, "Exploring entrepreneurial identity construction: the case of action-based entrepreneurship education," 2013.

[17] Z. Li, X. F. Li, and F. Y. Wan, "The development of the questionnaire of enterprise consciousness of undergraduate," Psychol. Explor., vol. 30, pp. 85-89, 2010.

[18] L. K. Muthen and B. O. Muthen, Mplus User's Guide (7th Edition). Los Angeles: CA, 2015.

[19] D. Harrington, Confirmatory Factor Analysis. Oxford: University Press, 2009.

[20] W. A. Naudé and W. F. Krugell, "The small business challenge facing Africa," Small Bus. Monit., vol. 1, no. 1, pp. 6469, 2003.

[21] W. A. Naudé and L. Van Der Walt, "Opportunity or necessity? The spatial determinants of entrepreneurship in South Africa," Int. J. Entrep. Small Bus., vol. 3, no. 2, pp. 245-265, 2006.

[22] B. Alma, Kewirausahaan (edisi revisi). Bandung: CV Alfabeta, 2010.

[23] K. F. Sadriwala and A. A. Khan, "Entrepreneurial self-efficacy and its impact on entrepreneurial intentions," Int. J. Manag. Sci. Bus. Res., vol. 7, no. 9, pp. 9-21, 2018.

[24] A. S. M. Ferreira, E. Loiola, and S. M. G. Gondim, "Motivations, business planning, and risk management: entrepreneurship among university students," RAI Rev. Adm. e Inovação, vol. 14, no. 2, pp. 1-11, 2017.

[25] I. Ajzen, "Organizational behavior and human decision processes," theory Plan. Behav., vol. 50, no. 2, pp. 179-211, 1991.

[26] S. Beugelsdijk and N. Noorderhaven, "Personality characteristics of selfemployed; An empirical study," Small Bus. Econ., vol. 24, no. 2, pp. 159-167, Mar. 2005, doi: 10.1007/s11187-0033806-3 
[27] F. H. Wijbenga, A. van Witteloostuijn, F. H. Wijbenga, and A. van Witteloostuijn, "Entrepreneurial locus of control and competitive strategies - The moderating effect of environmental dynamism," J. Econ. Psychol., vol. 28, no. 5, pp. 566-589, 2007, Accessed: Mar. 17, 2021. [Online]. Available: https://econpapers.repec.org/RePEc:eee:j oepsy:v:28:y:2007:i:5:p:566-589.
[28] D. M. Sullivan and W. R. Meek, "Gender and entrepreneurship: a review and process model," J. Manag. Psychol., vol. 27, no. 5, pp. 428-458, 2012.

[29] M. Israr and M. Saleem, "Entrepreneurial intentions among university students in Italy," J. Glob. Entrep. Res., vol. 8, no. 1, p. 20, Dec. 2018, doi: $10.1186 / \mathrm{s} 40497-$ 018-0107-5. 